\title{
EFFECT OF VARIOUS STORAGE CONDITIONS ON THE NUTRITIONAL PROPERTIES OF SOIME CUCURBITS
}

KEY WORDS: Nutraceuticals,

Vitamin C, Dietary fibre,

Dietetics, Storage, Cucurbits

\section{More Madhura \\ Department of Botany, PatkarVarde College, Goregaon West, Mumbai \\ Palathingal Trisa \\ Bhagat Sachin* \\ Department of Botany, PatkarVarde College, GoregaonWest, Mumbai \\ Department of Botany, Patkar Varde College, Goregaon West, Mumbai. *Corresponding Author}

Cucurbits belonging to family Cucurbitaceae or the gourd family of flowering plants, are very important nutritionally.
After harvest, storing of these cucurbits in optimal conditions is important to ensure that the nutrients are not lost. In the
present investigation, an attempt was made to study the effect of various storage conditions on the nutrient content of
three most commonly growing and easily available cucurbits, Cucumis sativus L. (Cucumber), Momordica charantia L.
(Bitter gourd) and Luffa acutangula L. (Shiradi, Luffa). It was observed that protein content, vitamin C, iron and crude fiber
content in all the cucurbits studied showed a gradual reduction with increase in days of storage. Temperature of storage
was also found to be an important factor for the nutrients to be maintained in Cucurbits. Storage at $15^{\circ} \mathrm{C}$ was found to be
better as the decrease in nutrients was found to be minimum when the fruits were stored at $15^{\circ} \mathrm{C}$ compared to storage at
room temperature and $5{ }^{\circ} \mathrm{C}$.

\section{INTRODUCTION}

Cucurbits are prostrate herbs bearing tendrils. They are nutritionally rich with high medicinal value. The nutritional quality of any Cucurbit is depending upon the presence of vitamins, fibers, carbohydrates, proteins and other nutrients Storing the cucurbits after harvest in optimal conditions is very important. The ideal storage condition for Cucumis is reported to be around 50 to $54^{\circ} \mathrm{F}$ (Wenjing Guan, 2017). Cucurbits are found to be sensitive to chilling. It is reported that chilling injury can develop when the fruits are stored below $50^{\circ} \mathrm{F}$ for more than 2 or 3 days. Devendra et. al. (2011), have observed variation in the cucurbitacin content in cucurbits with respect to time and temperature. The improper storage of cucurbits can change its bioactive compounds as well as its nutrients according to storage conditions (e.g., time and temperature). Therefore, it is necessary to store them in the most appropriate storage conditions. For the present work the effect of storage on three commonly cultivated cucurbits were studied.

\section{MATERIAL AND METHODS}

Plants selected

1) Cucumis sativus L. (Cucumber)

2) Momordica charantia L. (Bitter gourd)

3) Luffa acutangular L. (Shiradi, Luffa)

\section{Storage conditions}

The cucurbit fruits were stored under the following conditions for a definite period of time before analyzing them.

I) Room Temperature- The fruits were kept at room temperature for one, two and three days and then they were analysed for the different parameters and the data was recorded.

ii) $15{ }^{\circ} \mathrm{C}$ - The fruits were stored at a temperature of $15{ }^{\circ} \mathrm{C}$ for one, two and three days and then they were analysed for the different parameters and the data was recorded.

iii) $5{ }^{\circ} \mathrm{C}$ - The fruits were stored at a temperature of $5{ }^{\circ} \mathrm{C}$ for one, two and three days and then they were analysed for the different parameters and the data was recorded.

\section{Parameters Studied}

1. Iron content- The Iron content of the cucurbits, stored under different conditions was analysed using Farrar (1935) method

2. Vitamin C-TheVitamin $\mathbf{C}$ content of the cucurbits, stored under different conditions was analysed using DCPIP method.

3. Protein content- The protein content of the cucurbits stored under different conditions was analysed using Lowry's method.

4. Crude fibre content- The crude fibre content of the cucurbits, stored under different conditions was analysed using Acid Base method.

Table 1: Effect of different storage conditions and storage period on nutrient content of Cucumis sativus $\mathrm{L}$. (mg/g) Cucumis sativus L (Cucumber)

\begin{tabular}{|l|l|l|l|l|l|l|l|l|l|l|l|l|l|}
\hline $\begin{array}{l}\text { Sr. } \\
\text { No. }\end{array}$ & $\begin{array}{l}\text { Storage } \\
\text { Period }\end{array}$ & $\begin{array}{l}\text { Iron Content } \\
\text { Room } \\
\text { temp. }\end{array}$ & $\begin{array}{l}15^{\circ} \\
\text { Celsius }\end{array}$ & $\begin{array}{l}5^{\circ} \\
\text { Celsius }\end{array}$ & $\begin{array}{l}\text { Room } \\
\text { temp. }\end{array}$ & $\begin{array}{l}15^{\circ} \\
\text { Celsius }\end{array}$ & $\begin{array}{l}5^{\circ} \\
\text { Celsius }\end{array}$ & $\begin{array}{l}\text { Room } \\
\text { temp. }\end{array}$ & $\begin{array}{l}\text { Ro } \\
\text { Celsius }\end{array}$ & $\begin{array}{l}5^{\circ} \\
\text { Celsius }\end{array}$ & $\begin{array}{l}\text { Room } \\
\text { temp. }\end{array}$ & $\begin{array}{l}15^{\circ} \\
\text { Celsius }\end{array}$ & $\begin{array}{l}5^{\circ} \\
\text { Celsius }\end{array}$ \\
\hline 1$)$ & $1^{\text {st }}$ day & $0.4 \pm 0.1$ & $0.6 \pm 0.5$ & $0.3 \pm 0.1$ & $0.5 \pm 0.5$ & $0.9 \pm 0.6$ & $0.6 \pm 0.3$ & $0.2 \pm 0.7$ & $0.2 \pm 0.7$ & $0.2 \pm 0.6$ & $0.5 \pm 0.5$ & $0.6 \pm 0.3$ & $0.5 \pm 0.4$ \\
\hline 2$)$ & $2^{\text {nd }}$ day & $0.3 \pm 0.2$ & $0.5 \pm 0.6$ & $0.2 \pm 0.5$ & $0.3 \pm 0.6$ & $0.7 \pm 0.7$ & $0.4 \pm 0.3$ & $0.1 \pm 0.5$ & $0.1 \pm 0.6$ & $0.1 \pm 0.5$ & $0.4 \pm 0.5$ & $0.5 \pm 0.5$ & $0.4 \pm 0.5$ \\
\hline 3$)$ & $3^{\text {rd }}$ day & $0.1 \pm 0.4$ & $0.5 \pm 0.1$ & $0.2 \pm 0.1$ & $0.1 \pm 0.4$ & $0.5 \pm 0.7$ & $0.2 \pm 0.4$ & $0.01 \pm 0.5$ & $0.01 \pm 0.6$ & $0.01 \pm 0.5$ & $0.2 \pm 0.2$ & $0.5 \pm 0.2$ & $0.3 \pm 0.6$ \\
\hline
\end{tabular}

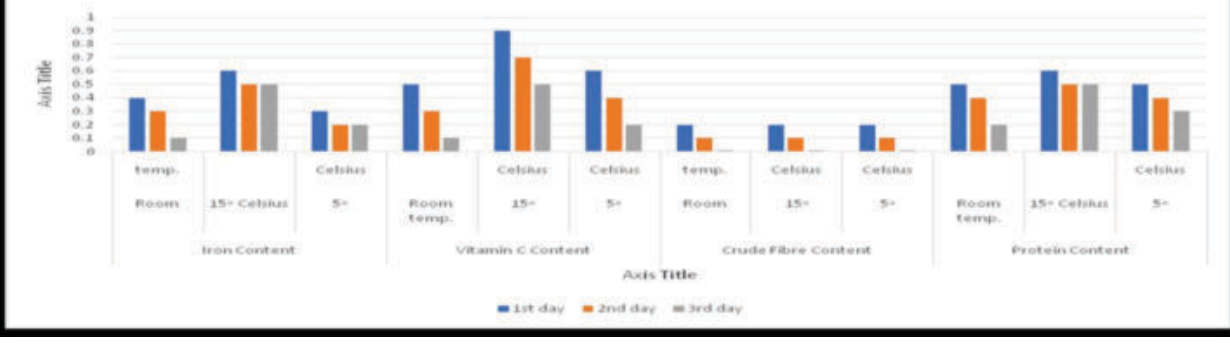


PARIPEX - INDIAN JOURNAL OF RESEARCH | Volume - $10 \mid$ Issue - 10 | October - $2021 \mid$ PRINT ISSN No. 2250 - 1991 | DOI : $10.36106 /$ paripex Table 2: Effect of different storage conditions and storage period on nutrient content of Luffa acutangular L. (mg/g) Momordica charantia L. (Bitter Gourd)

\begin{tabular}{|c|c|c|c|c|c|c|c|c|c|c|c|c|c|}
\hline \multirow{2}{*}{$\begin{array}{l}\text { Sr. } \\
\text { No. }\end{array}$} & \multirow{2}{*}{$\begin{array}{l}\text { Storage } \\
\text { Period }\end{array}$} & \multicolumn{3}{|c|}{ Iron Content } & \multicolumn{3}{|c|}{ Vitamin C Content } & \multicolumn{3}{|c|}{ Crude Fibre Content } & \multicolumn{3}{|c|}{ Protein Content } \\
\hline & & $\begin{array}{l}\text { Rom } \\
\text { temp. }\end{array}$ & $\begin{array}{l}15^{\circ} \\
\text { Celsius }\end{array}$ & $\begin{array}{l}5^{\circ} \\
\text { Celsius }\end{array}$ & $\begin{array}{l}\text { Room } \\
\text { temp. }\end{array}$ & $\begin{array}{l}15^{\circ} \\
\text { Celsius }\end{array}$ & $\begin{array}{l}5^{\circ} \\
\text { Celsius }\end{array}$ & $\begin{array}{l}\text { Room } \\
\text { temp. }\end{array}$ & $\begin{array}{l}15^{\circ} \\
\text { Celsius } \\
\end{array}$ & $\begin{array}{l}5^{\circ} \\
\text { Celsius }\end{array}$ & $\begin{array}{l}\text { Room } \\
\text { temp. }\end{array}$ & $\begin{array}{l}15^{\circ} \\
\text { Celsius }\end{array}$ & $\begin{array}{l}5^{\circ} \\
\text { Celsius }\end{array}$ \\
\hline 1) & $1^{\text {st }}$ day & $18 \pm 0.2$ & $20 \pm 0.2$ & $18 \pm 0.2$ & $6 \pm 0.4$ & $8 \pm 0.7$ & $7 \pm 0.4$ & $1.4 \pm 0.7$ & $1.8 \pm 0.6$ & $1.6 \pm 0.7$ & $0.7 \pm 0.3$ & $0.9 \pm 0.4$ & $0.8 \pm 0.4$ \\
\hline 2) & $2^{\text {nd }}$ day & $16 \pm 0.6$ & $18 \pm 0.1$ & $17 \pm 0.2$ & $4 \pm 0.6$ & $6 \pm 0.5$ & $5 \pm 0.3$ & $1.2 \pm 0.7$ & $1.4 \pm 0.7$ & $1.4 \pm 0.7$ & $0.6 \pm 0.3$ & $0.8 \pm 0.4$ & $0.7 \pm 0.3$ \\
\hline 3) & $3^{\text {rd }}$ day & $14 \pm 0.2$ & $17 \pm 0.1$ & $17 \pm 0.2$ & $3 \pm 0.6$ & $5 \pm .30$ & $4 \pm 0.3$ & $1.0 \pm 0.6$ & $1.2 \pm 0.6$ & $1.2 \pm 0.7$ & $0.4 \pm 0.4$ & $0.8 \pm 0.4$ & $0.6 \pm 0.8$ \\
\hline
\end{tabular}

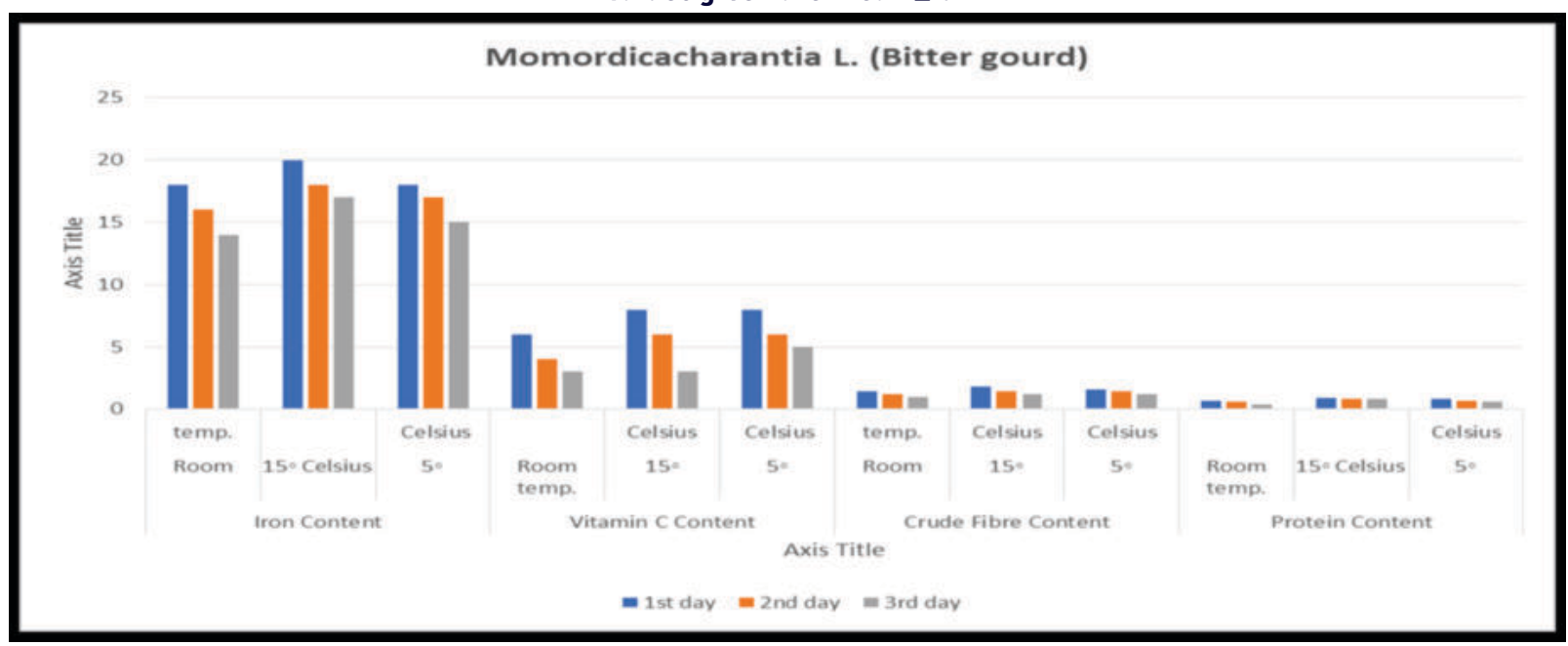

Table 3: Effect of different storage conditions and storage period on nutrient content of Luffa acutangula $\mathrm{L}$. (mg/g) Luffa acutangular L. (Shiradi, Luffa)

\begin{tabular}{|c|c|c|c|c|c|c|c|c|c|c|c|c|c|}
\hline \multirow{2}{*}{$\begin{array}{l}\text { Sr. } \\
\text { No. }\end{array}$} & \multirow{2}{*}{$\begin{array}{l}\text { Storage } \\
\text { Period }\end{array}$} & \multicolumn{3}{|c|}{ Iron Content } & \multicolumn{3}{|c|}{ Vitamin C Content } & \multicolumn{3}{|c|}{ Crude Fibre Content } & \multicolumn{3}{|c|}{ Protein Content } \\
\hline & & $\begin{array}{l}\text { Rom } \\
\text { temp. }\end{array}$ & $\begin{array}{l}15^{\circ} \\
\text { Celsius }\end{array}$ & \begin{tabular}{|l|}
$5^{\circ}$ \\
Celsius
\end{tabular} & $\begin{array}{l}\text { Room } \\
\text { temp. }\end{array}$ & $\begin{array}{l}15^{\circ} \\
\text { Celsius }\end{array}$ & $\begin{array}{l}5^{\circ} \\
\text { Celsius }\end{array}$ & $\begin{array}{l}\text { Room } \\
\text { temp. }\end{array}$ & $\begin{array}{l}15^{\circ} \\
\text { Celsius }\end{array}$ & \begin{tabular}{|l|}
$5^{\circ}$ \\
Celsius
\end{tabular} & $\begin{array}{l}\text { Room } \\
\text { temp. }\end{array}$ & $\begin{array}{l}5^{\circ} \\
\text { Celsius }\end{array}$ & \begin{tabular}{|l|}
$5^{\circ}$ \\
Celsius
\end{tabular} \\
\hline 1) & $1^{\text {st }}$ day & $\begin{array}{l}0.34 \pm \\
0.3\end{array}$ & $\begin{array}{l}0.36 \pm \\
0.3\end{array}$ & $\begin{array}{l}0.32 \pm \\
0.2\end{array}$ & $\begin{array}{l}0.5 \pm \\
0.4\end{array}$ & $\begin{array}{l}0.7 \pm \\
0.4\end{array}$ & $\begin{array}{l}0.6 \pm \\
0.2\end{array}$ & $\begin{array}{l}1.4 \pm \\
0.7\end{array}$ & $\begin{array}{l}1.8 \pm \\
0.6\end{array}$ & $\begin{array}{l}1.6 \pm \\
0.7\end{array}$ & $\begin{array}{l}0.11 \pm \\
0.3\end{array}$ & $\begin{array}{l}0.12 \pm \\
0.4\end{array}$ & $\begin{array}{l}0.12 \pm \\
0.4\end{array}$ \\
\hline 2) & $2^{\text {nd }}$ day & \begin{tabular}{|l|}
$0.32 \pm$ \\
0.2 \\
\end{tabular} & \begin{tabular}{|l|}
$0.33 \pm$ \\
0.4 \\
\end{tabular} & $\begin{array}{l}0.31 \pm \\
0.3\end{array}$ & $\begin{array}{l}0.4 \pm \\
0.3\end{array}$ & $\begin{array}{l}0.5 \pm \\
0.4\end{array}$ & $\begin{array}{l}0.5 \pm \\
0.4\end{array}$ & $\begin{array}{l}1.2 \pm \\
0.7\end{array}$ & $\begin{array}{l}1.4 \pm \\
0.7\end{array}$ & $\begin{array}{l}1.4 \pm \\
0.7\end{array}$ & $\begin{array}{l}0.9 \pm \\
0.5\end{array}$ & $\begin{array}{l}0.11 \pm \\
0.5\end{array}$ & $\begin{array}{l}0.11 \pm \\
0.4\end{array}$ \\
\hline 3) & $3^{\text {rd }}$ day & $\begin{array}{l}0.28 \pm \\
0.2\end{array}$ & $\begin{array}{l}0.32 \pm \\
0.3\end{array}$ & $\begin{array}{l}0.29 \pm \\
0.4\end{array}$ & $\begin{array}{l}0.3 \pm \\
0.0\end{array}$ & $\begin{array}{ll}0.4 \pm \\
0.2\end{array}$ & \begin{tabular}{|l|}
$0.4 \pm$ \\
0.3
\end{tabular} & $\begin{array}{l}1.0 \pm \\
0.6\end{array}$ & $\begin{array}{l}1.2 \pm \\
0.6\end{array}$ & $\begin{array}{l}1.2 \pm \\
0.7\end{array}$ & $\begin{array}{l}0.7 \pm \\
0.5\end{array}$ & $\begin{array}{l}0.11 \pm \\
0.5\end{array}$ & $\begin{array}{l}0.9 \pm \\
0.5\end{array}$ \\
\hline
\end{tabular}

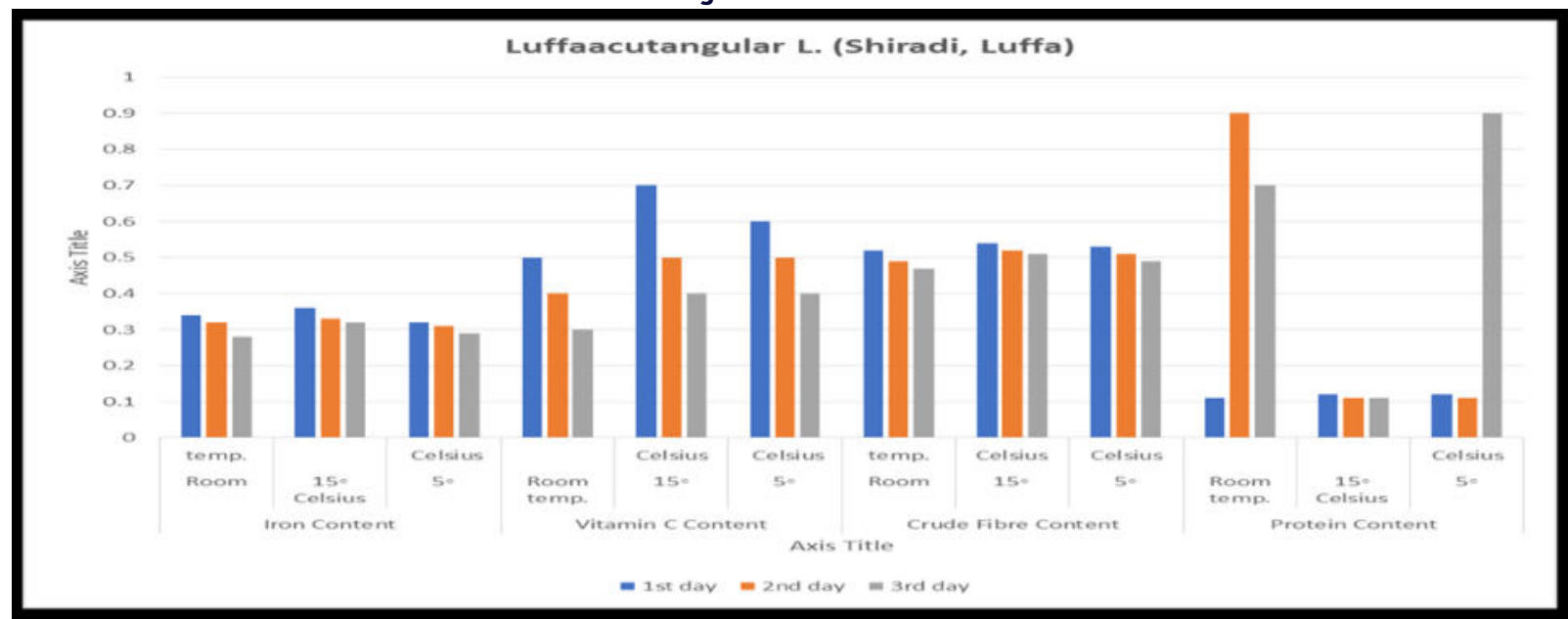

\section{RESULTS AND DISCUSSIONS}

In the present investigation it was observed that the protein content, vitamin $\mathrm{C}$, iron and crude fiber content in all the cucurbits studied showed a gradual reduction with increase in days of storage. The decrease in nutrients was found to be minimum when the fruits were stored at $15^{\circ} \mathrm{C}$ compared to room temperature and $5^{\circ} \mathrm{C}$.

Maximum iron content was observed in the fruits of Momordica charantia L compared to fruits of Cucumis sativus L and Luffa acutangula $\mathrm{L}$. The decrease in iron content was from 18 to $14 \mathrm{mg} / \mathrm{g}$ in the fruits of Momordica charantia stored at room temperature after one day of storage and three days of storage respectively (Table 1). Chunduri et. al. 2013 has recorded $177.3 \mathrm{mg} / 100 \mathrm{~g}$ of iron in Momordica charantia L fruits collected from Mumbai. In Cucumis sativus L. reduction in iron content observed was from 0.4 to $0.1 \mathrm{mg} / \mathrm{g}$ when stored at room temperature, The loss was less when the fruits were stored at $5^{\circ} \mathrm{C}$. Rahman et. al. 2006 has recorded $1.3 \mathrm{mg} / 100 \mathrm{~g}$ of iron in Cucumis sativus fruits. Luffa acutangula L. showed a decrease in iron content from 0.36 to $0.28 \mathrm{mg} / \mathrm{g}$ when stored at room temperature for one day and three days respectively (Table l). Bakare et al 2010 have also worked on iron content in cucurbits. Essien et. al. (2016) have stated that Cucumis sativus 
are among the most water rich foods and contain protein $(0.82 \%)$, Vitamin $\mathrm{C}$ content also showed a reduction in all the fruits studied due to storage. The reduction was found to be maximum in Cucumis sativus L fruits when stored in room temperature. The amount of vit $\mathrm{c}$ in Cucumis sativus $\mathrm{L}$ after one day of storage at room temperature was found to be $0.5 \mathrm{mg} / \mathrm{g}$ but after 3 days of storage at room temperature it reduced to $0.1 \mathrm{mg} / \mathrm{g}$.(Table2.)

Maximum crude fibre content was observed in the fruits of Momordica charantia L compared to fruits of Cucumis sativus L and Luffa acutangular $\mathrm{L}$. The amount of crude fibre present after one day of storage at room temperature in Momordica was found to be $1.4 \%$ while after one day of storage at $15{ }^{\circ} \mathrm{C}$ it was found to be $1.8 \%$ (Table 4 )

\section{CONCLUSION}

The nutritional quality of Cucurbits depends upon the presence of vitamins, fibers, carbohydrates, proteins and other nutrients.

Cucumis sativus L., Momordica charantia L. and Luffa acutangular $\mathrm{L}$. when stored under different temperatures showed variation in the quantity of vitamin $\mathrm{C}$, iron content, crude fibers and protein content. As the days of storage increased the nutrient content reduced.

Temperature is an important factor in storage, for the nutrients to be maintained in Cucurbits. Storage of cucurbits at $15{ }^{\circ} \mathrm{C}$ is better than storage at room temperature and $5{ }^{\circ} \mathrm{C}$ because maximum nutrients were found to be retained in storage at $15^{\circ} \mathrm{C}$.

\section{REFERENCES}

1. Bakare, R.I., Magbagbeola, O.A., Akinwande, A.I. and Okunowo O.W. (2010). Nutritional and chemical evaluation of Momordica charantia. Journal of Medicinal Plants Research.Vol 4(21) pp 2189-2193.

2. Chunduri, J. R. (2013). Antioxidant and nutritional analysis of edible cucurbitaceae vegetables of India. International Journal of Bioassays Vol. 2(08), 1124-1129.

3. Devendra N. K., Attard, E. G., Raghunandan, D., Seetharam, Y. N. (2011). Study on seasonal variation on the content of Cucurbitacin of various vegetative parts of Momordica charantia L., cucumerina L. var. cucumerina, International Journal of Plant Research. 1(1):25-28.

4. Essien, A. D., Ogbonna, O. J Abe, P. N., Nnaoma, I E. and Omoregha, C.U. (2016). Comparative studies of the phytochemistry, proximate analysis, mineral and vitamin compositions of the methanol leaf extracts of Cucumis sativus L. and Daucus carota L. International Journal of Pharmacological Research.Vol 6 (8) pp 282-285.

5. Farrar, G.E, JR (1935), The determination of iron in biological material J. Biol, chem 110,685-694

6. Lowry, O.H., N.J. Rosebrough, A.L. Farr, and R.J. Randall (1951) Protein Measurement with the Folin Phenol Reagent.J.Biol. Chem. 193:265-275

7. Rahman, A.H.M.M., Anisuzzaman M., Ahmed Ferdous, Rafiul I. A.K.M. and Naderuzzaman A.T.M. (2008). Study of nutritive value and medicinal uses of cultivated cucurbits.J.Applied Sci.Res., 4:555-558.

8. Wenjing Guan (2017) vegetable crops hotline, Purdue university 